\title{
A silent polymorphism in the $P E R 1$ gene associates with extreme diurnal preference in humans
}

\author{
Jayshan D. Carpen · Malcolm von Schantz • \\ Marcel Smits $\cdot$ Debra J. Skene $\cdot$ Simon N. Archer
}

Received: 5 July 2006/ Accepted: 24 August 2006/Published online: 19 October 2006

(C) The Japan Society of Human Genetics and Springer 2006

\begin{abstract}
The three PERIOD proteins form a major negative feedback component of the molecular mechanism governing the periodicity of the vertebrate circadian clock. Genetic variations within the human $P E R 2$ and PER3 genes have been linked with diurnal preference and disorders of sleep timing. We screened the coding region of PERl, as well as the $5^{\prime}$ - and $3^{\prime}$ untranslated regions and the promoter region, for polymorphisms. The T2434C polymorphism in exon 18 , a synonymous substitution, associated with extreme diurnal preference. The $\mathrm{C}$ allele was more frequent in subjects with extreme morning preference (frequency $=0.24)$ than in subjects with extreme evening preference (frequency $=0.12$ ). No significant association was observed between either allele and delayed sleep phase syndrome. This polymorphism may have a direct effect on RNA translatability, or be in linkage disequilibrium with another polymorphism which affects PER1 expression at the DNA, RNA, or protein level. This is the first reported association between a PER1 polymorphism and extreme diurnal preference. Functionally important polymorphisms in PER1 are rare, which may indicate that it is subject to more stringent selection pressure than the other PER genes.
\end{abstract}

J. D. Carpen - M. von Schantz - D. J. Skene ·

S. N. Archer $(\square)$

Centre for Chronobiology,

School of Biomedical and Molecular Sciences,

University of Surrey, Guildford

GU2 7XH, UK

e-mail: simon.archer@surrey.ac.uk

M. Smits

Department of Neurology and Sleep-Wake Disorders,

Hospital de Gelderse Vallei, 6710 Ede, The Netherlands
Keywords Biological clocks - Circadian rhythm sleep disorders · Circadian rhythms · Nucleocytoplasmic transport proteins $\cdot$ Single nucleotide polymorphism

\section{Introduction}

The circadian timing system governs multiple aspects of physiology and behaviour. The Period (Per) genes are a pivotal part of the molecular mechanism that generates circadian rhythms within the cells of eucoelomate animals. In vertebrates, the ancestral single Per gene has been multiplied into three paralogues, Per1, Per2, and Per3 (von Schantz et al. 2006). Studies on double knockout mice with only one functioning Per gene have shown that either Per1 or Per2 is sufficient to maintain free-running circadian rhythms in locomotor activity on its own (albeit with altered periodicity), whereas Per1/Per2 double knockout mice lack such rhythmicity (Bae et al. 2001).

A mutation in the coding region of the human PER2 gene has been shown to cause familial advanced sleep phase syndrome (ASPS), in which patients exhibit a circadian period approximately $4 \mathrm{~h}$ shorter than unaffected family members (Jones et al. 1999) (Toh et al. 2001). A polymorphism within the 5 '-untranslated region (UTR) of PER2 has been associated with diurnal preference in humans (Carpen et al. 2005). The human PER3 gene shows considerable polymorphism in the coding region (Ebisawa et al. 2001), including a haplotype characterised by a missense single-nucleotide polymorphism (SNP), as well as a variable number tandem repeat (VNTR) polymorphism affecting the length of the encoded protein. Both of these have been reported to associate with delayed sleep phase 
syndrome (DSPS), and the VNTR polymorphism with diurnal preference as well (Ebisawa et al. 2001; Archer et al. 2003; Pereira et al. 2005). No evidence was found for differential or balancing selection in the PER3 VNTR allele frequencies in different populations (Nadkarni et al. 2005). By contrast, the human PERI gene appears to be subject to a higher selection pressure. A synonymous substitution in the coding region of PER1, G2548A, has previously been reported not to associate with diurnal preference (Katzenberg et al. 1999), but no other polymorphisms in the human PER1 gene have been described in the literature since. Here, we report another synonymous polymorphism in this gene which does associate with diurnal preference.

\section{Materials and methods}

Buccal DNA samples and Horne-Östberg (HÖ) scores were obtained from 1,590 volunteers, as described earlier (Robilliard et al. 2002). The 5\% subjects with the lowest and highest HÖ scores with respect to their age were selected for genetic analysis $(n=80$ for each group). The high-scoring group (extreme morningness) consisted of 36 males and 44 females (average age \pm SD $37.1 \pm 10.6$ years), and the low-scoring group (extreme eveningness) also consisted of 36 males and 44 females (age 41.6 \pm 16.3 years). An intermediate group was identified by selecting the 80 subjects closest to the linear regression line (Robilliard et al. 2002) (42 males and 38 females, age $41.6 \pm 15.4$ years). Patients diagnosed with DSPS ( $n=23: 12$ males and 11 females, age $27.2 \pm 14.9$ years) were also analysed. The polymorphisms listed in the SNP database (dbSNP) and predicted to cause missense substitutions were selected and screened for by direct sequencing of PCR amplicons from pools of DNA samples obtained from subjects with extreme diurnal preference, as well as pools produced from specific ethnic groups (Coriell Institute, Camden, NY, USA) as described earlier (Carpen et al. 2005). No SNPs within the promoter region (Taruscio et al. 2000) or the 5'-and 3'-UTRs were listed at the time. These regions were amplified in a number of amplicons spanning their entire lengths from the same pools, and screened by direct sequencing. Through the screening procedure, the silent PER1 T2434C polymorphism was identified as a candidate by virtue of its differential distribution between the extreme morning and evening preference pools. However, an exhaustive screen for the presence of other silent polymorphisms was not performed. An ARMS (amplification refractory mutation system) protocol was developed for the rapid and specific identification of the two alleles of this SNP (Newton et al. 1991). The protocol was modified so that a region upstream of the SNP was amplified by the T-allele primer pair, whilst the C-allele primer pair amplified the adjacent downstream region. Primers were GTATGGATGTGTTGACCCCTGAA and CTGGGCCTGGGGCTAGA ( $\mathrm{T}$ allele) and TGGAGGACCTGCCTGGC and CCCCCAACAATCCAGTCCTA (C allele). Amplification was performed using the FastStart Taq DNA polymerase (Roche Applied Science, Basel, Switzerland). Thermocycling parameters were $95^{\circ} \mathrm{C}$ for $4 \mathrm{~min}$, followed by 30 cycles of $95^{\circ} \mathrm{C}$ for $30 \mathrm{~s}, 64^{\circ} \mathrm{C}$ ( T allele) or $61^{\circ} \mathrm{C}\left(\mathrm{C}\right.$ allele) for $30 \mathrm{~s}$, and $72^{\circ} \mathrm{C}$ for $1 \mathrm{~min}$. PCR products were assessed by agarose gel electrophoresis. A random selection of $20 \%$ of amplicons were verified by direct sequencing.

\section{Results}

Ten putative missense SNPs (T777C [dbSNP accession number rs3027177], A1056G [rs3027180], C1989T [rs3027184], G2558A [rs3027189], A2573T [rs3027190], G2736T [rs11658069], G3071C [rs2585405], G3090A [rs3027193], A3168G [rs3027194], G3266A [rs12937495]) were chosen from the PER1 polymorphisms listed in dbSNP. However, none of these were detected within pools of DNA obtained from subjects with extreme diurnal preference, or from selected ethnic groups. Screening of the $P E R 1$ promoter region and UTRs within the pooled DNA samples revealed no further polymorphisms. The silent PER1 T2434C polymorphism in exon 18 (dbSNP accession number rs2735611) was identified as a candidate by virtue of its differential distribution between the extreme morning and evening preference pools. The genotype distribution at this locus in the diurnal preference groups and

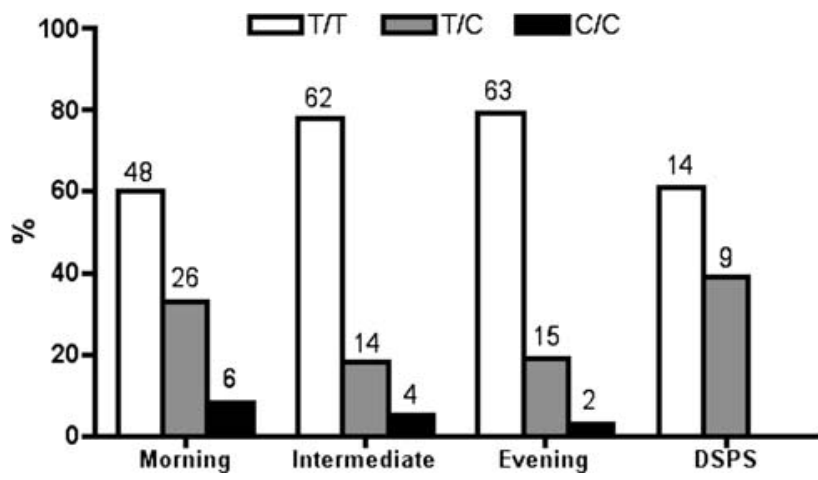

Fig. 1 PER1 T2434C genotype frequencies for subjects with intermediate or extreme morning/evening preference and DSPS patients. Absolute subject numbers for each genotype are indicated above each vertical bar 
in DSPS patients is shown in Fig. 1, and the allele frequencies in Table 1. All subject groups were in Hardy-Weinberg equilibrium, apart from the intermediate diurnal preference group $\left(\chi^{2}=5.499, P<0.02\right)$. The frequency of the $\mathrm{C}$ allele was significantly higher in subjects with extreme morning preference $(0.24)$ than in subjects with extreme evening preference (0.12) (Fisher's exact test, two-sided $P$ value $=0.0132$, odds ratio $=2.18$, confidence interval $=1.20-3.95$ ). No significant difference was observed in binary comparisons between the groups with extreme diurnal preference and subjects with intermediate diurnal preference. Neither was any significant difference observed between DSPS patients and any of the other groups. All samples selected for direct sequencing were verified as having been correctly genotyped by the ARMS protocol.

\section{Discussion}

Whilst a number of mutations and polymorphisms in the PER2 and PER3 genes have been reported to associate with circadian parameters in humans, this is the first such report with respect to PER1. The C2434 allele appears to be significantly associated with morningness, with no significant association observed between either allele and DSPS. Our screen for missense variants in PER1, or polymorphisms of potential functional importance in the promoter and $5^{\prime}$ - and $3^{\prime}$ UTRs was negative. This may be an indication that the human PERl gene is subject to more stringent selection constraints, a possibility that should be investigated further. The T2434C polymorphism in itself is silent, and does thus not affect the sequence of the translated protein. A difference of one nucleotide base may in itself affect mRNA translatability, as has been shown for an SNP in the coding region of the human dopamine receptor 2 gene (Duan et al. 2003). Based on predicted RNA folding, we have previously proposed an SNP in the 5'-UTR of the PER2 gene to affect diurnal preference in a similar fashion (Carpen et al. 2005). However, given that the PER1 T2434C

Table 1 PER1 T2434C allele frequencies for subjects with intermediate or extreme morning/evening preference and DSPS patients

\begin{tabular}{lll}
\hline & \multicolumn{2}{l}{ Allele frequencies } \\
\cline { 2 - 3 } & $T$ & $C$ \\
\hline Morning & 0.76 & 0.24 \\
Intermediate & 0.86 & 0.14 \\
Evening & 0.88 & 0.12 \\
DSPS & 0.80 & 0.20 \\
\hline
\end{tabular}

polymorphism does not cause any predicted difference in secondary RNA structure (data not shown), it is probably more likely that the phenotypic effect reported here reflects a second, unknown polymorphism in linkage disequilibrium with PER1 T2434C. Whilst, for reasons of gene function and vicinity, this would be most likely to be within the PER1 gene, or in a more distal region important in its regulation, it is also possible that the effect is due to a polymorphism in a different neighbouring gene not yet implicated in circadian function (Shimomura et al. 2001). Clearly, additional studies would be needed to confirm the usefulness of this marker, and to identify the functional significance of its genetic association with diurnal preference.

Acknowledgments This investigation was supported by an MRC studentship (to JDC). DJS is supported by the 6th Framework Project EUCLOCK (018471). We thank Adrian Williams (St Thomas' Hospital, London) for donating some of the DSPS samples.

\section{References}

Archer SN, Robilliard D, Skene DJ, Smits MG, Williams A, Arendt J, von Schantz M (2003) A length polymorphism in the circadian clock gene Per3 is linked to delayed sleep phase syndrome and extreme diurnal preference. Sleep 26:413-415

Bae K, Jin X, Maywood ES, Hastings MH, Reppert SM, Weaver DR (2001) Differential functions of mPer1, mPer2, and $m P e r 3$ in the SCN circadian clock. Neuron 30:525-536

Carpen JD, Archer SN, Skene DJ, Smits MG, von Schantz M (2005) A single-nucleotide polymorphism in the 5'-untranslated region of the $h P E R 2$ gene is associated with diurnal preference. J Sleep Res 14:293-297

Duan J, Wainwright MS, Comeron JM, Saitou N, Sanders AR, Gelernter J, Gejman PV (2003) Synonymous mutations in the human dopamine receptor D2 (DRD2) affect mRNA stability and synthesis of the receptor. Hum Mol Genet 12:205-216

Ebisawa T, Uchiyama M, Kajimura N, Mishima K, Kamei Y, Katoh M, Watanabe T, Sekimoto M, Shibui K, Kim K, Kudo Y, Ozeki Y, Sugishita M, Toyoshima R, Inoue Y, Yamada N, Nagase T, Ozaki N, Ohara O, Ishida N, Okawa M, Takahashi K, Yamauchi T (2001) Association of structural polymorphisms in the human period3 gene with delayed sleep phase syndrome. EMBO Rep 2:342-346

Jones CR, Campbell SS, Zone SE, Cooper F, DeSano A, Murphy PJ, Jones B, Czajkowski L, Ptacek LJ (1999) Familial advanced sleep-phase syndrome: A short-period circadian rhythm variant in humans. Nat Med 5:1062-1065

Katzenberg D, Young T, Lin L, Finn L, Mignot E (1999) A human period gene (HPER1) polymorphism is not associated with diurnal preference in normal adults. Psychiatr Genet 9:107-109

Nadkarni NA, Weale ME, von Schantz M, Thomas MG (2005) Evolution of a length polymorphism in the human PER3 gene, a component of the circadian system. J Biol Rhythms 20:490-499 
Newton C R, Graham A, Heptinstall L E, Powell S J, Summers C, Kalsheker N, Smith J C, Markham A F (1991) Analysis of any point mutation in DNA. The amplification refractory mutation system (ARMS). Nucleic Acids Res 17:2503-2516

Pereira DS, Tufik S, Louzada FM, Benedito-Silva AA, Lopez AR, Lemos NA, Korczak AL, D'Ameida V, Pedrazzoli M (2005) Association of the length polymorphism in the human Per3 gene with the delayed sleep-phase syndrome: does latitude have an influence upon it? Sleep 28:29-32

Robilliard D, Archer SN, Arendt J, Lockley SW, Hack LM, English J, Leger D, Smits MG, Williams A, Skene DJ, von Schantz M (2002) The 3111Clock gene polymorphism is not associated with sleep and circadian rhythmicity in phenotypically characterized human subjects. J Sleep Res 11:305312 von Schantz M, Jenkins A, Archer SN (2006) Evolutionary history of the vertebrate Period genes. J Mol Evol 62:701-707 Shimomura K, Low-Zeddies SS, King DP, Steeves TD, Whiteley A, Kushla J, Zemenides PD, Lin A, Vitaterna MH, Churchill GA, Takahashi JS (2001) Genome-wide epistatic interaction analysis reveals complex genetic determinants of circadian behavior in mice. Genome Res 11:959-980

Taruscio D, Zoraqi GK, Falchi M, Iosi F, Paradisi S, Di Fiore B, Lavia P, Falbo V (2000) The human per1 gene: genomic organization and promoter analysis of the first human orthologue of the Drosophila period gene. Gene 253:161170

Toh KL, Jones CR, He Y, Eide EJ, Hinz WA, Virshup DM, Ptacek LJ, Fu YH (2001) An hPer2 phosphorylation site mutation in familial advanced sleep phase syndrome. Science 291:1040-1043 